\title{
En funktionel semantik funderet på økologisk psykologi
}

\author{
SIMON BORCHMANN
}

Artiklens udgangspunkt er at de etablerede sprogvidenskabelige beskrivelser af meddelelser hverken er retvisende eller informative når de anvendes på meddelelser der indgår i udøvelsen af aktiviteter. Problemet lokaliseres til de etablerede beskrivelsers semantiske og pragmatiske grundlag. For at løse problemet foreslås en semantik der er funderet på den økologiske psykologis teori om handlemuligheder (affordances). Den pragmatiske grundantagelse i den alternative semantik er at meddelelser bruges til at dele vardier forstået som informationer om handlemuligheder. To basale semantiske strukturer postuleres. Den første er en relation mellem en angivelse af en værdi, fx sydøst, og en identifikation af den måde at skelne på der skal anvendes i forståelsen af den angivne værdi, fx vindretning. Den anden er en relation mellem en angivelse af en værdi, fx sydøst, og en angivelse af betingelsen for værdien, $\mathrm{fx} i$ aften. Påstanden er at disse to strukturer regulerer udformningen af meddelelser. Denne alternative semantik muliggør en retvisende karakteristik og informativ analyse af meddelelser der indgår i udøvelsen af aktiviteter.

EMNEORD: affordances, funktionel semantik, meddelelsesstruktur, informationsstruktur

I denne artikel vil jeg beskrive to basale, men ikke desto mindre ubeskrevne strukturer der regulerer udformningen af meddelelser i den dagligsproglige sprogbrug. Jeg har tidligere (Borchmann 2015a, 2015b) beskrevet de to strukturer med udgangspunkt i de etablerede beskrivelser af naturlige sprogs meddelelsesstruktur (herefter EBSM). I denne artikel vil jeg beskrive dem på deres egne præmisser og som semantiske strukturer der indgår i en overordnet meddelelsesfunktion.

Motivationen for at udvikle en ny semantisk beskrivelse er at der viser sig nogle uoverensstemmelser når man anvender EBSM på medde- 
lelser der indgår i udøvelsen af aktiviteter, og at uoverensstemmelserne kan føres tilbage til EBSM's semantiske grundlag. Det kan illustreres med følgende paradigmatiske eksempel som jeg løbende vil forholde mig til i artiklen:

1) it's three thousand RVR

(CVR-transskription, Southwest 1248, National Transportation Safety Board 2007)

Ytringen stammer fra cockpittet på et passagerfly i planlægningen af indflyvningen forud for en landing der resulterede i en overskridelse af landingsbanen med tab af menneskeliv til følge (National Transportation Safety Board 2007). Sekvensen ytringen indgår i, er følgende:

17:34:55.8 Kaptajn: gotta have three thousand

17:34:57.1 Andenpilot: he sent me a dispatch message

17:35:00.3 Kaptajn: okay

17:35:00.8 Andenpilot: and he said fair and three thousand RVR

17:35:03.4 Kaptajn: alright it's three thousand RVR we can do it

Med ytringen bekræftede kaptajnen at den aktuelle sigtbarhed (Runway Visual Range) på landingsbanen 31C på destinationen Chicago Midway var 3000 fod, og at RVR-kravene for at lande på 31C dermed var opfyldt. Bekræftelsen var en del af grundlaget for beslutningen om at forsøge at lande på 31C. Havde RVR-værdien været 2800 fod eller mindre, havde landingsbanen ikke været tilgængelig. Og da de andre landingsbaner ikke var tilgængelige på grund af RVR-kravene, ville kaptajnen have haft et grundlag for at vælge en anden lufthavn med de ekstraomkostninger det ville have påført flyselskabet. Men alt andet lige med en mindre risiko for en overskridelse af landingsbanen; for friktions- og vindforholdene på 31C viste sig siden at være tæt på marginerne for at flyet kunne nå at standse. Og det var medvirkende til at en lille forsinkelse i kaptajnens aktivering af en bremseanordning på motorerne fik flyet til at overskride landingsbanen.

I henhold til den minimale konsensus inden for EBSM er ytringen en tetisk sætning og dermed emneløs (Kuroda 1972, Sasse 1987, Lam- 
brecht 1994, Kuroda 2005); der meddeles ikke information om noget med den. I stedet karakteriserer man den således at den bruges til at postulere eksistens (Sasse 1987) eller til at introducere en diskursreferent der så efterfølgende meddeles noget om (Lambrecht 1994). Ligeledes karakteriseres ytringen ved at have all-new character (Kuno 1972, Lambrecht 1994), dvs. at man angiveligt ikke kan skelne mellem de informationsstrukturelle statusser af a) den værdi der angives med "three thousand", b) den afgrænsede mængde af værdier der identificeres med udtrykket "RVR", og c) den værdi der angives med tempusbøjningen af verbet. Læseren bemærker at henvisningerne har nogle år på bagen; men analyserne og karakteristikkerne anvendes igen og igen og gengives i state of the art-artikler (fx Krifka \& Musan 2012). Også i de nyeste beskrivelser af tetiske sætninger i dansk (Togeby 2003, Hansen \& Heltoft 2011) finder man dem.

Så galt står det faktisk til. Disse misvisende funktionelle karakteristikker og lidet informative analyser er en konsekvens af at man forudsætter at information er sandhedsbetingelser, og at prædikationen er den grundlæggende meddelelseskonstituerende struktur. En simpel prædikation er en tildeling af en egenskab, klasse eller rolle til en referent og omfatter en reference og et prædikat. Referencen til en entitet gør det muligt at afgøre om tildelingen af egenskaben, klassen eller rollen er sand eller falsk (Gundel 2012). Når man i EBSM må anse ytringer som 1 for emneløse, er det fordi man forbinder sætningens emne med det referentielle udtryk i prædikationen og antager at det grammatiske subjekt typisk varetager denne opgave. Og når man må bestemme ytringen som all-new, er det dels fordi man forbinder den informationelle status givet med de referentielle udtryk i prædikationen, dels fordi udtryksstørrelser som $R V R$ ikke anses for referentielle $i$ en sætningskontekst som den aktuelle.

Fundamentet for disse semantiske antagelser er en epistemologi hvor kognition og handling er adskilt, og en hermed forbunden præference for sprogbrug hvor taleren afbilleder sagforhold, og hvor lytteren er tilskuer til det der afbildes (Borchmann 2015b). Det er et legitimt valg at basere en beskrivelse på et hjørne af sprogbrugen; problemet opstår når sådanne beskrivelser fremsættes som generelle beskrivelser af meddelelsers form, funktion og virkning. 
De uoverensstemmelser jeg har påvist, peger på at der er behov for en semantik der kan danne grundlag for beskrivelser af meddelelser der indgår i udøvelsen af aktiviteter, fx at lande et fly, og hvor lytteren udøver den aktivitet meddelelsen relaterer sig til semantisk. En sådan beskrivelse kalder på et nyt epistemologisk grundlag. Den økologiske psykologi adskiller sig netop fra ovennævnte epistemologi ved at antage at kognition og handling ikke kan adskilles, og at information er information om handlemuligheder. Den forekommer derfor at have et særligt potentiale som grundlag for en retvisende og informativ beskrivelse af sprogbrug der indgår i udøvelsen af aktiviteter, og af naturlige sprog som redskab til at dele information. Den semantiske beskrivelse der præsenteres, er baseret på teorien om handlemuligheder. Den grundlæggende antagelse er at udøvere af aktiviteter bruger sproget til kommunikere om handlemuligheder.

I første sektion redegøres der for det teoretiske grundlag for beskrivelsen. I anden sektion afgrænses det empiriske grundlag for beskrivelsen. I tredje sektion følger så beskrivelen af to semantiske strukturer der indgår i en overordnet meddelelsesfunktion. Der afsluttes med en sammenfatning.

\section{TEORIEN OM AFFORDANCES SOM GRUNDLAG FOR EN SEMANTIK}

\subsection{Sprog og formål}

I problematiseringen af EBSM har jeg henvist til deres semantiske og epistemologiske grundlag. Det skal derfor fremhæves at det ikke er de begreber og antagelser der udgør grundlaget, jeg problematiserer, men det at man anvender disse begreber og antagelser som grundlag for beskrivelser af meddelelsers generelle form, funktion og virkemåde. Jeg er altså ikke ude i et sprogfilosofisk, epistemologisk ærinde. Mit ærinde er sprogvidenskabeligt, og den erkendelsesinteresse der styrer det videnskabelige arbejde jeg præsenterer nogle resultater af, er retvisende og informative beskrivelser af meddelelser i dagligsproglig sprogbrug.

Den sprogvidenskabelige tilgang er funktionel. Denne karakteristik er vag og dækker over flere forskellige tilgange. I denne artikel vil jeg imidlertid holde mig til en bred karakteristik fordi den muliggør en 
sammenligning mellem antagelser i den semantik EBSM er baseret på, og den semantik jeg udvikler. Den grundlæggende antagelse i en funktionel tilgang er at sproglige former er bestemt af det sproget bruges til. I overensstemmelse hermed anvendes en teleologisk forklaringsmodel. Det indebærer at udgangspunktet for en semantisk beskrivelse er et svar på følgende to pragmatiske spørgsmål: 1) Hvilke formål tjener den dagligsproglige sprogbrug? og 2) hvilke opgaver skal et sprog varetage for at tjene disse formål? Argumentativt er svarene på spørgsmål 1 og spørgsmål 2 henholdsvis en hypotese og en deduktion ud fra hypotesen.

Når den grundlæggende antagelse formuleres så bredt, kan man med en vis ret sige at den deles af den semantik EBSM er baseret på. Det er ganske vist ikke altid at svaret på spørgsmålet om formålet ekspliciteres i de semantiske beskrivelser det indbefatter; men der findes ekspliciteringer. Nedenstående eksplicitering er udvalgt med omhu fordi Strawson netop anvender en teleologisk forklaringsmodel og netop afleder antagelsen om prædikationen som en basal semantisk struktur ud fra et generelt formål:

One of the main purposes of language is the purpose of stating facts about things and persons and events. If we want to fulfill this purpose, we must have some way of forestalling the question, 'What (who, which one) are you talking about?' as well as the question, 'What are you saying about it (him, her)?' The task of forestalling the first question is the referring (or identifying) task. The task of forestalling the second is the attributive (or descriptive or classificatory or ascriptive) task. (Strawson 2004 (1950))

Den struktur de to beskrevne relaterede opgaver udgør, svarer til prædikationen: en reference og en tildeling af en egenskab, klasse eller rolle til referenten. Da antagelsen om denne struktur er afledt af formålet, og da antagelsen blokerer for en retvisende funktionel karakteristik og informativ analyse af ytringer som (1), indikerer det altså - idet jeg antager at beskrivelsen er konsistent - at svaret på det pragmatiske spørgsmål om formålet, "stating facts about things and persons and events", er forkert, og at der må findes et nyt svar. I hvert fald når det drejer om sprogbrug som den cockpitinteraktionen er et eksempel på. 
$\mathrm{Nu}$ har jeg ganske vist tilkendegivet at jeg ikke er ude i et filosofisk ærinde, men det er ikke så nemt at give et svar på dette spørgsmål uden at forholde sig til ontologiske og epistemologiske spørgsmål; man skal jo ikke tænke længe over Strawsons svar, før det bliver klart at det indebærer nogle antagelser om hvad verden er, og hvad det er vi perciperer ("things and persons and events"), og hvad viden og information er ("facts"). Det gælder også det alternative svar jeg foreslår:

Et af hovedformålene med et sprog er at dele værdier.

Dette svar er baseret på nogle antagelser om hvad det er vi perciperer, og hvad viden og information er. Disse antagelser adskiller sig fra dem Strawsons svar indebærer. Dette problem omgås ved at betragte uoverensstemmelserne som et resultat af en forskel i perspektiv. Det antages således at sproget kan undersøges under flere perspektiver, og at det ene ikke udelukker det andet. Det er derfor at jeg i formuleringen af formålet - ligesom Strawson - angiver at det er et blandt flere andre hovedformål. Et perspektiv kan imidlertid have større forklaringsværdi end et andet for nogle områder af sprogbrugen. Og min påstand er så at resultaterne af en undersøgelse af sprog i det perspektiv jeg anlægger, har større forklaringsværdi for et bestemt område af sprogbrugen end resultaterne af en undersøgelse i det perspektiv man anlægger i den semantik EBSM er baseret på.

I det følgende afsnit beskrives de teoretiske antagelser som mit svar på det pragmatiske spørgsmål om formålet er baseret på. I sektion 2 indskrænkes det område af sprogbrugen jeg hævder at beskrivelsen har en forklaringsværdi i forhold til.

\subsection{Handlemuligheder og information}

Den semantiske beskrivelse der præsenteres, er baseret på den økologiske psykologis teori om handlemuligheder og det begreb om information der knytter sig til den: Begrebet 'værdi' i formålsbestemmelsen ovenfor er simpelthen en pragmatisk, kommunikationsorienteret tillempning af dette begreb. I det følgende skal teorien beskrives med særlig henblik på dens potentiale som grundlag for en semantik. Termen vardi vender jeg tilbage til i afsnit 1.3 . 


\subsubsection{Handlemuligheder}

Hvis man betragter semantikken som en beskrivelse af relationen mellem sprog og verden, er det ikke uvæsentligt hvordan dem der bruger sproget, perciperer verden. Den økologiske psykologi er netop kendetegnet ved en særlig tilgang til perception: I stedet for at tage udgangspunkt $i$ vores sanseapparat tages der udgangspunkt $i$ den verden vi må forholde os til perceptuelt $i$ og med at vi lever. Rationalet bag er evolutionært: Vores perceptuelle evne er et resultat af det selektionspres der øves på vores art; den er vores tilpasning til det miljø vi lever i.

Den grundlæggende antagelse i den økologiske psykologi er at det vi perciperer, er de handlemuligheder - til fordel eller ulempe - miljøet tilbyder i forhold til de evner vi besidder som organismer (Gibson 1986). Disse handlemuligheder kaldes affordances ${ }^{1}$. Et eksempel på en handlemulighed er den mulighed for at sidde ned en stol kan tilbyde. Det interessante ved affordance-begrebet i semantisk sammenhæng er dels at handlemuligheden er relativ til den der perciperer, dels at perceptionen af handlemuligheden er uafhængig af kategoriseringen af genstanden. Hvad det første angår, beror sid-ned-barhed på bestemte egenskaber ved en overflade, bl.a. at den er plan, flad, udstrakt og fast og har en bestemt højde. Disse egenskaber kan anses for fysiske egenskaber hvis de måles med de skalaer og standardenheder man anvender i fysikken. Som en handlemulighed må de imidlertid måles relativt både til organismens art og til individer af arten. Et rådyr perciperer ikke ovennævnte fysiske egenskaber som sid-ned-barhed, og det gør et menneske heller ikke hvis højden ikke svarer til menneskets knæhøjde. Gibsons pointe er vel at mærke ikke at der ikke er sådan noget som en observatøruafhængig, fysisk verden, og heller ikke at den verden organismer forholder sig til, er en indre, privat verden. Pointen er at organismer basalt set ikke perciperer verden i fysikkens dimensioner (abstrakt tid og rum) og enheder (fx lysår og atomer), men i de dimensioner og enheder der er relevante for deres liv. Den verden mennesker lever i og forholder sig til perceptuelt, beskriver Gibson med det økologiske begreb niche, og han foreslår så at betragte en niche som en mængde handlemuligheder.

1 Jeg vælger her at oversætte affordances til handlemuligheder da Gibson selv bruger udtrykket action possibilities. 
Hvad perceptionens uafhængighed af kategoriseringen angår, gælder det at man ikke behøver at kunne kategorisere stolen for at kunne percipere de handlemuligheder den tilbyder. Gibson skriver:

\begin{abstract}
The fact that a stone is a missile does not imply that it cannot be other things as well. It can be a paperweight, a bookend, a hammer, or a pendulum bob. It can be piled on another rock to make a cairn or a stone wall. These affordances are all consistent with one another. The differences between them are not clear cut, and the arbitrary names by which they are called do not count for perception. If you know what can be done with a graspable detached object, what it can be used for, you can call it whatever you please.

The theory of affordances rescues us from the philosophical muddle of assuming fixed classes of objects, each defined by its common features and then given a name. As Ludwig Wittgenstein knew, you cannot specify the necessary and sufficient features of the class of things to which the name is given. They have only a "family resemblance." But this does not mean you cannot learn how to use things and perceive their uses. You do not have to classify and label things in order to perceive what they afford. (Gibson 1986: 134)
\end{abstract}

I de referencesemantikker EBSM er baseret på, er det karakteristisk at der er overensstemmelse mellem perception og kategorisering af genstande: Verden består grundlæggende af fysiske genstande (førsteordensentiteter) vi kan referere til og kategorisere ved prædikation, og det er også disse genstande vi perciperer (se fx Lyons 1977: 442-443). Med teorien om handlemuligheder driver Gibson derimod en kile ned mellem perception og kategorisering; som det fremgår af citatet, forankres perceptionen i den praktiske, brugsorienterede omgang med verden. Men samtidig, og nok bemærkelsesværdigt i denne sammenhæng, driver Gibson altså også en kile ned mellem perception og sprog: Det vi har navne for, er ikke det vi perciperer. Denne adskillelse er mere generelt formuleret i følgende refleksion der optræder i forlængelse af et afsnit hvor Gibson fremstiller sit økologiske alternativ til den klassiske fysiske beskrivelse af verden: 
Everything in the above paragraph has long been known implicitly by practical men - the surveyors of the earth, the builders, and the designers of the environment. It is tacit knowledge (Polanyi, 1966). This description is superior because it is appropriate to the study of the perception and behavior of animals and men as a function of what the environment affords. (Gibson 1986: 22)

Den viden vi besidder $\mathrm{i}$ og med at vi kan percipere, udnytte og skabe de handlemuligheder et miljø tilbyder, anser Gibson altså for tavs.

1.2.2 Information. I teorien om handlemuligheder er information information om handlemuligheder; det er de egenskaber ved miljøet der gør at vi perciperer handlemuligheder. Information er altså ikke noget der er i hovedet på os eller transporteres fra en bevidsthed til en anden. Information omgiver os; det er alt det som bla. det omgivende lys, den omgivende lyd og lugt og berøringer formidler om verden. Disse stimuli varierer kontinuerligt $i$ og med vi bevæger os, og i og med genstande og substanser omkring os bevæger sig. Det vi oplever, er med andre ord et flux (James 1890, Gibson 1986). Det afgørende i den økologiske tilgang er at disse stimuli ikke desto mindre har struktur, dvs. at der er noget der er invariant $\mathrm{i}$ den kontinuerlige variation. Og det er ifølge Gibson disse strukturer der er informationsbærende. Gibsons antagelse er så at det er sådanne strukturer vi perciperer, og at vi gør det direkte, dvs. uden medierende begrebslige repræsentationer. Denne relation mellem information og handlemuligheder beskrives sådan at information specificerer handlemuligheder. Det betyder dels at relationen er lovmæssig, dels at det er en en-til-en-relation. Det sidste skal forstås sådan at information der specificerer en handlemulighed, udgør en enhed. Mens det kan være fristende at anse egenskaber som plan, flad og stiv som noget der specificerer sid-ned-barhed, peger Gibson på at sådanne benævnelige egenskaber blot er delvise abstraktioner fra en rig perceptuel enhed. 
1.2.3 Affordancebegrebets potentiale som grundlag for en semantik. Som Gibson fremstiller teorien om handlemuligheder, synes den altså ikke at have relevans for en semantisk beskrivelse. Slet ikke endda. Hvad man imidlertid skal bemærke, er at Gibson i citatet om stenen ovenfor faktisk forudsætter at vi bruger sproget til at benævne genstande, og at ord er betegnelser for klasser af genstande. Også Polanyi, som Gibson henviser til i citatet om tavs viden, synes at tage udgangspunkt i sådan en semantik (Polanyi 1966: 5-6). Den centrale pointe i den økologiske funderede semantik jeg præsenterer, er at Gibsons adskillelse af handlemuligheder og sprog er baseret på den antagelse at vi bruger sproget til at benævne fysiske genstande og kategorisere dem. Derforuden er adskillelsen et resultat af at Gibson kun i meget begrænset omfang inddrager redskabsmedieret adfærd. Det er således min påstand at vi (også) bruger sproget til at kommunikere om handlemuligheder, og at alt hvad vi behøver at gøre for at vise det, er at opgive den ide at vi generelt bruger sprog til at benævne fysiske genstande og kategorisere dem, og at undersøge sprogbrug der indgår i redskabsmedierede, materielle aktiviteter.

At affordancebegrebet har et potentiale i en semantisk beskrivelse, kan illustreres med eksempel (1). Det piloterne kommunikerer om i planlægningen af indflyvningen, er netop handlemuligheder på godt og ondt. Faktisk angiver Gibson selv sigtbarhed som et eksempel på en handlemulighed: "Air (...) When illuminated and fog-free, it affords visual perception" (Gibson 1986: 130-131). Relationen mellem den aktuelle sigtbarhed (RVR) på landingsbanen 31C og lyden three thousand $R V R$ er ganske vist medieret af en række redskaber, herunder måleinstrumenter og sproglige strukturer. Men det ændrer for det første ikke på den aktuelle sigtbarheds status som en handlemulighed på godt og ondt for piloterne - en handlemulighed de er nødt til at percipere af hensyn til det tilsigtede udfald af indflyvningen. For det andet gælder det dels at piloterne vil være i stand til at percipere denne handlemulighed under selve indflyningen til 31C, dels at vi ikke på forhånd kan afvise at de faktisk perciperer den bestemmelse af handlemuligheden den sproglige udtryksform three thousand RV R udgør, direkte, dvs. uafhængigt af mentale repræsentationer. 
Eksempel (1) taler for affordancebegrebets relevans for en semantisk beskrivelse, men peger samtidig på en tilsyneladende uoverensstemmelse mellem den redskabsmedierede relation mellem information og handlemuligheder og den økologiske psykologis antagelse om en specifikationsrelation mellem information og handlemuligheder. Denne uoverensstemmelse har jeg tidligere negligeret (se Borchmann 2015a, 2015b). Og det er en fejl. Hvis man vil basere en semantik på teorien om handlemuligheder, må uoverensstemmelsen opløses. En sådan opløsning er dog ikke mulig inden for denne artikels rammer. Her vil jeg begrænse mig til en tillempning af den redskabsmedierede relation til specifikationsrelationen med udgangspunkt $i$ to af den økologiske psykologis egne begreber, nemlig opsamling af information og perceptuel læring.

1.2.4 Opsamling af information og perceptuel laring. I henhold til den økologiske psykologi er perceptionen aktiv. Det er altså ikke sådan at stimuli regner ned over hovedet på os så at sige; vi opsøger information for at guide vores handlinger og opnå kendskab til vores omgivelser (Gibson \& Pick 2000: 20), fx drejer vi hovedet for at se om der er cyklister bagude på cykelstien, og vi stikker hånden ind under en vandstråle for at mærke hvor varmt vandet er. Denne aktive perception kaldes opsamling af information (information pick up) (Gibson 1986). Begrebet opsamling af information indebxrer at det vi perciperer med, ikke er et sanseorgan, fx et øje; det er et øje i en muskulatur i et hoved på en hals der er en del af en krop med lemmer - med alle de muligheder det giver os; vi kan gå rundt om noget, tage det op og dreje det i hænderne, banke på det osv. Denne helhed kaldes et perceptuelt system (perceptual system) og er en evne til at uddrage invarianser af et flux, herunder skelne variationer (Gibson 1969, Gibson 1986, Gibson \& Pick 2000, Adolph \& Kretsch 2015). Som det fremgik af 1.2.1, er denne evne et resultat af evolutionen; det er fylogenetisk set vores tilpasning til miljøet. Det unikke ved denne evne er at den ontogenetisk set kan forfines i det uendelige i det aktive møde med miljøet, herunder gennem vejledning af omsorgspersoner (Gibson 1969, Gibson \& Pick 2000, Zukow-Goldring $\&$ Arbib 2007). Det er denne forfinelse termen perceptuel laring dækker 
over. Perceptuel læring er en afstemning (attumement) af det perceptuelle system til nichen.

Begreberne opsamling af information og perceptuel læring er af afgørende betydning for semantikkens fundering i teorien om handlemuligheder fordi de indebærer muligheden for at øvede udøvere af aktiviteter perciperer sproglige bestemmelser af handlemuligheder som enheder og ikke som delvise abstraktioner (se 1.2.2). Dernæst peger de os i retningen af en alternativ forståelse af begreber og af sprogets opgaver i udøvelsen af aktiviteter. Denne mulighed og den alternative forståelse af begreber er grundlaget for at beskrive den redskabsmedierede relation som en tilnærmelse til en specifikationsrelation. Det er således min påstand 1) at sproglige bestemmelser af handlemuligheder er perceptuelle enheder, og 2) at sådanne bestemmelser kan opsamles direkte. Sådanne bestemmelser kalder jeg R-specifikationer hvor $\mathrm{R}$ står for redskabsmedierede. Argumenterne for denne tillempning følger her.

1.2.5 R-specifikationer - en tilnarmelse til specifikationsrelationen. Når man karakteriserer relationen mellem den aktuelle sigtbarhed på 31C og lyden three thousand $\mathrm{R} V \mathrm{R}$ som medieret, anlægger man et tredjepersonsperspektiv; man hæver sig op over piloterne og danner et abstrakt scenarie der omfatter både den aktuelle sigtbarhed på 31C og lyden three thousand RVR. Når der er tale om en opsamling af information, må man imidlertid anlægge et førstepersonsperspektiv, dvs. piloternes. I dette perspektiv er de relevante spørgsmål: Hvilken information opsamler piloterne, og må de opsamle i omgivelserne for at handle hensigtsmæssigt, og hvilke stimuli omgiver dem? Den information piloterne opsamler og må opsamle, er information om sigtbarheden på 31C; den eneste kilde til information om sigtbarheden i de stimuli der omgiver dem, er grafik (dispatcherens meddelelse der vises på et display) og lyd. Man kan godt hævde at den perception af sigtbarheden piloterne har under selve indflyvningen til 31C, adskiller sig fra perceptionen af lyden three thousand $\mathrm{R} V \mathrm{R}$. Men hvis man hævder at den første er rigere og mere enhedslig end den sidste, får man problemer med at afgrænse perceptionen som en perception af en specifikation af en handlemulighed: Ud fra hvilke kriterier er perceptionen af sigtbarheden under 
selve indflyvningen rigere og mere enhedslig? Måske nok ud fra æstetiske, men ikke ud fra økologiske, funktionelle kriterier. Mit argument er at man kun kan afgrænse perceptionen som enhed ved henvisning til handlemuligheden. Og det eneste kriterium for at handlemuligheden er perciperet, er den handling der er guidet af information om handlemuligheden - i piloternes tilfælde deres forsøg på at lande på 31C. Det der gør de stimuli som lyden three thousand $R V R$ udgør, til en perceptuel enhed, er altså at perceptionen af dem er en nødvendig og tilstrækkelig betingelse for perceptionen af handlemuligheden, og at der er ydre kriterier for at handlemuligheden er perciperet.

I henhold til begrebet perceptuel læring er det man lærer når man lærer at opsamle information, at skelne. Når et barn lærer at kravle, lærer det bl.a. at skelne de afstande mellem to tilstødende platforme der tilbyder kravle-over-barhed, fra de afstande der ikke gør (Adolph 2008). Det barnet tilegner sig ved denne læringsproces, er hverken en mental repræsentation eller et mentalt sprog, men en aktivitetsspecifik. (Adolph 2008) evne til at skelne handlemuligheder i de omgivne stimuli. Noget tilsvarende gælder piloterne: Den perceptuelle læring deres adfærd i planlægningen af indflyvningen er et tegn på, er en tilegnet evne til at skelne mellem sigtbarheder som specifikationer af handlemuligheder $i$ en indflyvning. Det er heller ikke en mental model eller et mentalt sprog; under selve indflyvningen skal piloterne kunne se landingsbanen fra en bestemt højde, og hvis de ikke kan, skal de afbryde landingen. Hele det system af redskaber og handlinger kommunikation om sigtbarhed udgør, er motiveret af og konstrueret under hensynet til denne basale, ikkesproglige evne: visuel perception af en landingsbane $i$ en given højde over landingsbanen på en given afstand under givne vejrforhold. Uden denne evne intet system og ingen forudsætninger for at bruge de redskaber det omfatter, hensigtsmæssigt. For så vidt har Gibson ret i sin grundantagelse om at perception går forud for sprog, udtrykt i det prægnante diktum "Perceiving precedes predicating" (Gibson 1986: 260). Men den opfattelse af begreber og sproglige udtryks betydning diktummet er baseret på, er forkert. Det der ud fra ideen om perceptuel læring må være kriteriet for at vi har tilegnet os et begreb, fx det begreb vi på dansk bl.a. bruger udtryksformen afstand om, er ikke at vi har tilegnet os en mental repræsentation, men at vi 
ud fra ydre kriterier at dømme er i stand til at skelne en mængde af specifikationer af handlemuligheder i de omgivne stimuli, fra andre mængder af specifikationer af handlemuligheder i de omgivne stimuli. Barnet der kravler ud over en dyb forsænkning mellem to tilstødende platforme og falder ned og slår sig fordi afstanden mellem de to platforme er for stor, kan ikke meningsfuldt siges at have tilegnet sig det begreb vi bl.a. bruger udtryksformen afstand om. I henhold til ideen om perceptuel læring er et begreb altså ikke en mental repræsentation der overføres fra en person til en anden, men ganske simpelt en evne til at skelne. I den semantiske beskrivelse der præsenteres, kaldes den aktivitetsspecifikke evne til at skelne mellem specifikationer af handlemuligheder $\mathrm{i}$ en mængde af specifikationer af handlemuligheder, $\mathrm{fx}$ sigtbarhed i aktiviteten flyvning, for en måde; og det skal forstås som en tilegnet måde at regulere handling og opmærksomhed på (Reed 1996: 176-177).

Denne opfattelse af begreber har også nogle konsekvenser for forståelsen af sproglige udtryks betydning. I udøvelsen af aktiviteter bruges sproglige udtryk ikke først og fremmest til at overføre mentale repræsentationer, men til at regulere opmærksomhed. En udtryksform som $R V R$ er et redskab til at henlede opmærksomheden på en afgrænset mængde af specifikationer af handlemuligheder - en instruks til lytteren/lxseren om at anvende sin evne til at skelne mellem disse specifikationer. En udtryksform som three thousand er et redskab til at skelne specifikationer af handlemuligheder inden for en afgrænset mængde af specifikationer af handlemuligheder. Hvis man forstår begreber og sproglige udtryks mening på denne måde, kan man hævde at sproglige bestemmelser af handlemuligheder opsamles direkte, dvs. uafhængigt af mentale repræsentationer.

På disse punkter er der altså en lighed mellem den redskabsmedierede relation og specifikationsrelationen. Der hvor den redskabsmedierede relation adskiller sig, er med hensyn til lovmæssigheden. Relationen mellem en redskabsmedieret bestemmelse af en handlemulighed og handlemuligheden er ikke lovmæssig. Man kan anføre at vi udformer instrumenter således at der er en kausal relation mellem bestemmelsen af handlemuligheden og selve handlemuligheden, og at vi ligeledes bestræber os på at udforme tegnsystemer der gør det muligt at bestemme 
handlemuligheder præcist og korrekt, ligesom vi sanktionerer upræcis og ukorrekt sproglig bestemmelse af handlemuligheder. Vi forsøger med andre ord at konstruere og opretholde en lovmæssig relation. Men det gør ikke relationen lovmæssig i streng forstand: Instrumenter kan være upræcise og misvisende, og sproglige bestemmelser kan være upræcise og ukorrekte.

Af disse grunde bruger jeg termerne R-specificerer og R-specifikation om en redskabsmedieret bestemmelse af en handlemulighed. $R$ angiver at relationen er medieret af et redskab, og at den kun er tilnærmet lovmæssig. $\mathrm{R}$ modificerer de økologiske psykologiske termer specificere og specifikation således at de begrænser sig til at dække over en relation der er kendetegnet ved at være en en-til-en-relation, dvs. at specifikationen er en perceptuel enhed, og ved at være direkte, dvs. at specifikationen kan opsamles uafhængigt af mentale repræsentationer.

Med beskrivelsen af den økologiske psykologi og tillempningen af specifikationsrelationen er forudsætningerne for beskrivelsen af termen vardi til stede.

\subsection{Værdier}

Det skelsættende ved den økologiske psykologi i forhold til den epistemologi EBSM er baseret på, er at den ikke beskriver vores stræben efter mening (Bartlett 1932) som et forsøg på at etablere og fremsætte fakta (facts), men som en stræben efter værdier (values). Det er en konsekvens af det økologiske perspektiv og det hermed forbundne begreb niche; dermed bliver det vi efterspørger og forsøger at tilvejebringe og realisere, det der er af værdi for vores liv. Nu dækker liv imidlertid over mange og meget forskellige former for menneskelig adfærd; og det er forskelligt fra aktivitet til aktivitet hvad der mere specifikt udgør en værdi. I den semantik der præsenteres her, løses dette problem ved at anvende aktiviteten som en model af nichen. I det følgende afsnit afgrænses brugen af ordet aktivitet, og derefter følger en redegørelse for den særlige brug af ordet vardi i svaret på det pragmatiske spørgsmål om formålet. 
1.3.1 Aktiviteter ${ }^{2}$ I den økologiske funderede semantik defineres en aktivitet som en organisering af værdiregulerede (Hodges \& Baron 1992, Hodges 2007, Hodges 2009), redskabsmedierede (Vygotsky 1978) materielle handlinger med henblik på at opnå et tilsigtet udfald. Det omfatter $\mathrm{fx}$ at lande et fly, afgive skud med en riffel mod et byttedyr, samle svampe til et måltid, harpunfiske, dykke med flaske, brygge øl, spille bridge, køre landevejscykelløb, flyve dragefly, køre til arbejde i bil, tage et kreditforeningslån og en ufattelig mængde andet.

For samtlige disse aktiviteter gælder det at de sigter på at opnå et bestemt udfald. Fx er det tilsigtede udfald af at afgive skud med en riffel mod et byttedyr at skuddet er dræbende, dvs. at byttedyret bliver ramt således at det ikke er i stand til at flygte uden for skyttens rækkevidde, og at det dør inden for en tidsramme af ca. to minutter. Det afgørende i den økologisk funderede semantik er at udfaldet er materielt og ikkesprogligt. Når det er afgørende, er det fordi det er i kraft heraf at der er ydre kriterier for forståelsen af et udtryk. Fx er piloternes forsøg på at lande på 31C kriteriet på forståelsen af udtrykket three thousand $\mathrm{R} V \mathrm{R}$. Sprog anses med andre ord udelukkende for at være et middel til et mål. I indflyvningen er sprogbrugen et middel til at sikre at man overlever landingen, og ikke et mål i sig selv. Denne materielle, ikkesproglige ramme tjener samtidig som en forklaring på hvordan sociale restriktioner på brugen af udtryksformer kan opstå. De materielle, ikkesproglige handlinger og udfaldet af dem er grundlaget for dannelsen og stabiliseringen af semantiske restriktioner, ligesom det i sidste instans er ved henvisning til det materielle, ikkesproglige udfald af aktiviteter at restriktionerne kan legitimeres og brugen af udtryk kan sanktioneres.

Termen vardiregulerede kommer fra Hodges' teori om værdirealisering. Ifølge Hodges er værdier grundlæggende for de aktiviteter en niche omfatter; de er bestemmende for udvælgelsen, koordineringen og revideringen af mål og handlemuligheder (Hodges 2007). Værdier har altså forrang for mål ligesom det i sidste instans er dem der styrer tolkningen af specifikationer af handlemuligheder som handlingsvejledninger. Fx er sikkerhed en dominerende værdi i planlægningen af en indflyvning. Denne værdi styrer tolkningen af angivelsen af en RVR-

2 Denne fremstilling er baseret på Borchmann (2015b) og omfatter direkte gengivelser af formuleringer. 
værdi som en handlingsvejledning, og denne tolkning kan foranledige en revidering af målet med indflyvningen, at lande på Chicago Midway 31C.

Termen medieret $\mathrm{i}$ redskabsmedieret kommer fra Vygotsky (1978: 26). I sammensætningen bruges den om den gensidige afhængighed mellem redskaber og aktiviteter: redskabernes udformning er bestemt at aktiviteten, og udøvelsen af aktiviteten er betinget af redskaberne.

1.3.2 Vardier. I den økologisk funderede semantik kaldes en invarians der R-specificerer en handlemulighed, en vardi. Et eksempel på en værdi er den RVR-værdi på 3000 fod der meddeles i planlægningen af indflyvningen. Da Hodges bruger termen vardi om noget andet, kan det forekomme uhensigtsmæssigt at kalde R-specifikationer for værdier. Men der er væsentlige grunde til ikke desto mindre at gøre det. For det første bruger man i dagligsproget netop udtrykket vardi om opsamlede informationer om handlemuligheder som en RVR på 3000 fod. For det andet er der det forunderlige ved den økologiske psykologi at observatøruafhængige, fysiske, målbare tilstande som sigtbarheder faktisk er værdier i etisk, normativ forstand. Det er konsekvensen af at lægge det økologiske begreb niche ned over en fysisk beskrivelse af verden; dermed ækvivaleres den matematiske, deskriptive brug af termen vardi med den etiske, normative: I udøvelsen af en aktivitet er de R-specifikationer af handlemuligheder der opsamles, per definition handlingsvejledende. RVR-værdien 3000 fod tilsiger kaptajnen at forsøge at lande på Chicago Midway 31C. Hvis kaptajnen ikke handler i overensstemmelse med det værdien tilsiger, er det moralsk angribeligt.

Et anskueliggørende eksempel på denne forunderlige ækvivalens mellem fysik og etik finder man i nedenstående udveksling mellem jægere i en debattråd på internettet. Den der begynder tråden, indleder med en beretning om en jagt hvor han har skudt to rådyr. Han beretter bl.a.:

Bukkelammet (etårsbukken) blev skudt på ca. $344 \mathrm{~m}$ afstand, målt vha. afstandsmåler (...) Spisbukken [sic] faldt for en god bladkugle på $477 \mathrm{~m}$ afstand også målt 
vha. afstandsmåler. (www.jagtdebatten.dk, den 1. april ${ }^{3}$ 2012, hentet ned den 19. februar 2016)

Angivelserne af de værdier afstandsmåleren viste ved afgivningen af skuddene, mødes med følgende fordømmelser: "svineri", "føj", "FORKASTELIGT", "usmagelig", "ikke ansvarligt", "uforsvarligt", "helt utilstedelig", "sgu IKKE iorden", "inhuman jagt", "du skulle skamme dig" og "skam dig" (www.jagtdebatten.dk, hentet ned den 19. februar 2016). Problemet er at afstandene 344 meter og 477 meter i henhold til de generelle værdier der regulerer aktiviteten, ikke tilbyder den handling jægeren udførte. Disse værdier foreskriver bl.a. at man minimerer risikoen for anskydning, og risikoen for at anskyde dyret når man skyder på disse afstande, er for stor. De målte værdier 344 og 477 meter tilsiger således jægeren at undlade at skyde eller bevæge sig nærmere byttet.

Den tredje og sidste grund til at anvende udtrykket værdi er at vi stræber efter at tilvejebringe R-specifikationer af handlemuligheder, og at vi derfor kan formodes at anse dem for værdifulde. Det er de to nævnte værdier gode eksempler på: At vi har udviklet transmissometre og afstandsmålere, er netop et udtryk for denne stræben efter at tilvejebringe værdier.

Når der er taget udgangspunkt i målbare fysiske værdier, er det vigtigt at tilføje at affordancebegrebet omfatter handlemuligheder der er resultatet af menneskelig aktivitet. Gibson er selv opmærksom på dette forhold (Gibson 1986: 130). Men hvad han ikke kommer ind på, er den ændring af selektionspresset denne ændring af nichen indebærer (Deacon 1997, Odling-Smee et al. 2003, Harder 2010), og det forhold at en del af disse nye handlemuligheder beror på social mellemkomst i form af kollektiv tildeling af statusfunktioner (Searle 1995, Harder 2010). Således omfatter værdier også prisen 699 kr., hastighedsgrænsen 70 $\mathrm{km} / \mathrm{t}$, en 4-3-3-3-fordeling i bridge, renten $2 \%$ i optagelsen af et realkreditlån og 9.280 personlige stemmer ved et folketingsvalg. Talværdier er illustrative for sammenligningen af den økologiske og den fysiske beskrivelse af verden; men begrebet værdi omfatter vel at mærke en-

3 Det var ikke en aprilsnar. Skulle læseren undre sig over datoen, kan det anføres at jagten foregik i Skotland. 
hver specifikation af en handlemulighed der kan angives med sproget eller et andet redskab, fx en svamps bitre smag, en avocados blødhed, sidevind i et landevejscykelløb, luftsusen $\mathrm{i}$ et sår ved førstehjælp, rustfrit stål som en skrues materiale i et monteringsarbejde og fraværet af cyklister bagude på cykelstien ved højresving i bil.

Denne brug af termen værdi betyder ikke at jeg afstår fra at bruge Hodges' begreb om værdier. Der er behov for begge begreber i en retvisende og informativ beskrivelse af meddelelser som redskaber til at dele information. I den økologisk funderede semantik skelnes der således mellem værdier i Hodges' forstand, dvs. generelle værdier der regulerer en aktivitet, og som vi stræber efter at realisere, og værdier i betydningen R-specifikationer af handlemuligheder som vi stræber efter at opsamle (se 1.2.4), tilvejebringe og dele. Når ikke andet er angivet, bruger jeg udtrykket vardier i sidstnævnte forstand.

\section{DET EMPIRISKE GRUNDLAG: UDØVERSPROGBRUG}

Det empiriske grundlag for de semantiske strukturer der fremstilles i næste sektion, er det jeg kalder udoversprogbrug ${ }^{4}$. Udøversprogbrug kan illustreres ved følgende autentiske eksempel. En morgen før jeg begyndte at arbejde, overvejede jeg om jeg skulle tage ud at harpunfiske om aftenen. Da jeg har en vis erfaring med dykning, ved jeg dels at sigtbarheden $i$ vandet spiller en afgørende rolle for fangstmulighederne og for oplevelsens kvalitet, dels at vindforholdene influerer på sigtbarheden, og det sådan at bestemte vindforhold kan tjene som en prædiktor for dårlig sigt. Derfor gik jeg ind på DMI’s hjemmeside for at søge information om vindforholdene. Her opsamlede jeg bl.a. følgende informationer: "svag til jævn vind omkring sydøst" og "I aften og i nat". Det var tilstrækkeligt til at jeg opgav at tage ud at harpunfiske; for den kyststrækning jeg har adgang til i nærområdet, er østvendt, og med en pålandsvind på op til næsten otte sekundmeter er der relativt stor sandsynlighed for at sigtbarheden er så dårlig at jeg hverken kan opnå det tilsigtede udfald at fange fisk eller realisere de generelle værdier der regulerer aktiviteten, bl.a. at få en god oplevelse.

4 Denne fremstilling af udøversprogbrug er baseret på Borchmann (2015a) og Borchmann (2015b) og omfatter flere direkte gengivelser af formuleringer. 
De tre umiddelbart iagttagelige kendetegn ved udøversprogbrug er at den forstås som en handlingsvejledning, at den har handlekonsekvenser, og at der er ydre kriterier for forståelsen - i dette tilfælde at jeg ikke tager ud at fiske. Betingelsen for at udtryksformer som de ovenstående kan være handlingsvejledende og have konsekvenser, er følgende: 1) sprogbrugen kan bidrage til at øge sandsynligheden for at aktiviteten realiserer de værdier der regulerer aktiviteten, og får det tilsigtede udfald; 2) læseren/lytteren udøver den aktivitet som sprogbrugen kan påvirke udøvelsen og udfaldet af; 3) læseren/lytteren har et aktivitetsbestemt behov for at læse/lytte, og det er dette behov der motiverer forståelsen og gør at sprogbrugssituationen opstår; og 4) det sprogbrugen kognitivt set relaterer sig til, er ikke en viden, men en evne, nemlig en evne til at omsætte perceptionen af sproglige udtryksmønstre til handlekonsekvenser.

Udøversprogbrug kan så defineres således: Udøversprogbrug er sprogbrug der indgår i en aktivitet med henblik på at øge sandsynligheden for at aktiviteten realiserer de værdier der regulerer udøvelsen af aktiviteten, og får et tilsigtet udfald.

Det forhold at sprogbrugen relaterer sig til en evne, danner grundlag for et skel mellem to typer af udøversprogbrug. Således kan udøversprogbrug være relateret til evnen på to forskellige måder: Der er udøversprogbrug der forudsætter en evne, og så er der udøversprogbrug der er motiveret af en utilstrækkelig evne. Den første kalder jeg informativ udoversprogbrug; den er kendetegnet ved at den forsyner læserne/lytterne med de informationer som de i kraft af deres evne til at udøve en aktivitet - og netop i kraft af denne evne - er opmærksom på og efterspørger i udøvelsen. Denne sprogbrug er således informativ i forhold til den øvede udøvers valg mellem handlingsalternativer eller handlemåder. Eksemplet med harpunfiskeren ovenfor der opsamler information om vindretning og vindstyrke, er informativ udøversprogbrug. Den anden type, der altså er motiveret af en utilstrækkelig evne, kalder jeg formativ udoversprogbrug. Den er kendetegnet ved at den bidrager til opøvelsen og udviklingen af evnen til at udøve en aktivitet. Det er fx dykkermanualforfatterens til dykkereleven: "Sigtbarhed kan have stor indflydelse på dit dyk, så sigten er en af de første ting du bør finde ud af." (PADI Open Water Diver Manual: 126). Formativ sprogbrug sigter 
med andre ord på at understøtte opøvelsen af evnen til at opsamle de informationer der er relevante for udøvelsen af aktiviteten. Men denne evne kan vel at mærke ikke opøves alene ved sprogbrug; opøvelsen beror på udøvelsen af aktiviteten, men sprogbrug kan understøtte den.

Det empiriske grundlag for de strukturer der beskrives, er informativ udøversprogbrug.

\section{TO BASALE STRUKTURER DER REGULERER UD- FORMNINGEN AF MEDDELELSER}

Den pragmatiske antagelse der danner grundlag for denne semantik, er at sproglige meddelelser bruges til at dele værdier, dvs. R-specifikationer af handlemuligheder. En meddelelse defineres som en symbolsk angivelse af en værdi med henblik på at dele denne værdi med mennesker der besidder en evne til at skelne værdien fra andre værdier og har et motiv til at gøre det. For at kunne opfylde dette formål må sproget varetage nogle funktioner, dvs. formålsbestemte relationer mellem semantiske opgaver. I denne sektion skal disse funktioner beskrives.

\subsection{Variationer og måder}

De værdier der deles ved hjælp af meddelelser $\mathrm{i}$ informativ udøversprogbrug, er midlertidige. Eksempelvis varierer RVR-værdien på et givet sted, ligesom den der bevæger sig, vil percipere variation i værdier. Værdien 3000 fod afhænger således af tidspunktet og hvilken landingsbane det er. Når det er sådanne værdier der meddeles i informativ udøversprogbrug, er det dels fordi de er handlingsvejledende, dels netop fordi de varierer. Opsamlingen af disse værdier er forudsætningen for at tilpasse handlinger til omstændighederne og dermed handle hensigtsmæssigt. Det er derfor også disse variationer den øvede udøver tildeler opmærksomhed i udøvelsen af en aktivitet.

Øvede udøvere af aktiviteter er kendetegnet ved at kunne skelne mellem de værdier det er relevant at skelne mellem for at handle sådan at man realiserer de værdier der regulerer aktiviteten, og optimerer sandsynligheden for at opnå det tilsigtede udfald. I aktiviteten bilkørsel er det fx relevant at skelne mellem hastigheder, afstande til den forankørende, momenter med hvilket der trædes på bremsen osv. I andre ak- 
tiviteter er det fx relevant at skelne mellem vindretninger, vindstyrker, vindtyper, topografiske effekter på vindhastighed, stigningsprocenter, arbejdsintensiteter, kadencer, vejgreb, dæktryk, indfaldsvinkler, temperaturer, kogetider, renter, kurser, løbetider, vægte, priser, kortfordelinger, sandsynligheder og ufatteligt meget mere.

Evnen til at skelne mellem værdier af en variation det er relevant at være opmærksom på i udøvelsen af en aktivitet, kaldes i den økologisk funderede semantik en måde (se 1.2.5). Måder er opøvet ved perceptions- og handlingskredsløb i udøvelsen af aktiviteten. Det er gennem sådanne kredsløb udøverens perceptuelle system afstemmes til aktiviteten (se 1.2.4).

\subsection{Den basale semantiske struktur mådevardi}

I henhold den pragmatiske antagelse der danner grundlag for denne semantik, er det man gør med en meddelelse i udøversprogbrug, at angive en værdi med henblik på at dele den. I informativ udøversprogbrug er den værdi der skal deles, en del af et udfaldsrum, nemlig de værdier variationen omfatter, og som formelt set svarer til en afgrænset mængde af gensidigt udelukkende værdier af samme enhed, fx er mængden af RVR-værdier følgende: [100, 200, 300, 400, 500, 600, 700, $800,1000,1200,2400,2600,2800,3000,3500,4000,4500,5000,5500$, $6000,6500]^{5}$. Den semantiske struktur der regulerer udformningen af en meddelelse, må følgelig omfatte to opgaver: at angive en værdi og at identificere variationen og dermed også den måde der skal anvendes $i$ opsamlingen af den angivne værdi. Den første opgave kaldes angivelsen af vardien der skal deles, den anden identifikationen af delingsmåden. Relationen mellem en værdi og en måde er en udelukkelsesrelation; ved angivelsen af værdien udelukkes de øvrige værdier i den mængde af værdier måden formelt set udgør. Når kaptajnen i eksempel (1) siger "it’s three thousand RVR", gør han således tre ting; han identificerer den

5 RVR-værdien er en automatisk genereret værdi og meddeles i henhold til Federal Aviation Administration (2006) i 100 fods-intervaller fra 0 til 800, i 200 fods-intervallet fra 800 til 3000 og i 500 fods-intervaller fra 3000 til 6500 . Hvis værdien er over 6500, meddeles den ikke. Meddeles værdien ikke, tillader det antagelsen at sigtbarheden (RVR) er god: Andenpilot: "it didn't give me an RVR"; Kaptajn: "good...it's good." (CVR-transskription, Colgan Air 3407, den 12. februar 2009). 
mængde af værdier måden formelt set udgør, angiver en værdi i denne mængde og udelukker dermed de øvrige værdier i mængden. Som det vil fremgå senere, er der to formålsbestemte måde-værdi-relationer; for at skelne dem fra hinanden kaldes den relation der beskrives i dette afsnit, delingsfunktionen.

Epistemologisk set svarer denne struktur til at etablere en relation mellem et perceptuelt system og en niche, eller mere specifikt mellem en måde og en værdi. Den svarer med andre ord til at percipere. Den beskrevne struktur er altså ikke et unikt sprogligt fænomen; det er ganske simpelt den basale relation vi som mennesker er i til omgivelserne. Vi skubber til omgivelserne på bestemte måder, fx ved at lægge hånden på en radiator for at mærke om den er varm, og omgivelserne skubber igen, i eksemplet med stimuli der specificerer temperaturen. Måden er en indsnævring af opmærksomheden og dermed også en forventning. Hvad indsnævringen angår, kan radiatoren i eksemplet, foruden at have en temperatur, også være hvid, hård og underdimensioneret; den kan larme, der kan være luft i den, termostaten kan sidde fast, og bæringerne kan sidde løst. Men det er ikke det man er opmærksom på, når man lægger hånden på radiatoren for at mærke om den er varm. Hvad forventningen angår, forventer man at den har en temperatur og ikke en hvilken som helst temperatur. Ud fra erfaringer med radiatorer forventer man at temperaturen ligger inden for et område, og afhængig af den aktivitet den perceptuelle handling indgår $i$, skelner man mere eller mindre fint inden for dette område. Det jeg har karakteriseret formelt som en afgrænset mængde af værdier, er altså reelt set en forventning der kendetegner en fokuseret perceptuel handling udført af et aktivitetsafstemt perceptuelt system.

Et afgørende forhold for forståelsen og beskrivelsen af denne struktur som en semantisk struktur er at vi har udviklet redskaber der er $i$ en relation til omgivelserne svarende til denne struktur. Det er fx transmissometeret der tilvejebringer RVR-værdien 3000 fod, og afstandsmåleren der tilvejebringer værdierne 344 og 477 meter. Og det er målebånd, vægte, vinkelmålere, skydelærer, vaterpas, afstandsmålere, kompas, momentnøgler, ure, kalendere, termometre, anemometre, manometre, hygrometre, voltmetre, speedometre, pulsmålere, valutaer, priser, renter, kurser og ikke mindst sprog - ethvert redskab der op- 
deler miljøet i enheder der er relevant for vores liv. Disse redskaber har gjort det muligt at tilvejebringe og dele værdier og dermed koordinere handlinger og forøge sandsynligheden for at realisere værdier og opnå tilsigtede udfald af aktiviteter. De har bidraget til udviklingen af aktiviteter (Vygotsky 1978) som har selekteret for de egenskaber det fordrer at indgå i disse aktiviteter (Deacon 1997, Odling-Smee et al. 2003, Harder 2010), og øvet et pres på individet for at opøve evnen til udøve aktiviteterne. Disse redskaber ændrer således på vores evne til at skelne, både fylogenetisk og ontogenetisk.

Delingsfunktionen kan realiseres af kombinationen af et udtryk der angiver en værdi, og et udtryk der identificerer en måde. Fx (identifikation af måde med understregning og angivelse af værdi med fed):

2) Forudsat korrekt tempo er vinderchancen 74 pct. (Bridgeodds: 64)

3) og der er rigtig god sigtbarhed i dag (Tandemdragepilot til passager, den 8 . august 2015)

4) Med en 100 grains Oryx er der en afdrift på $44.3 \mathrm{~cm}$ ved $5 \mathrm{~m} / \mathrm{s}$ på 300 meter (Riffeljæger til andre riffeljægere, www.jagtdebatten.dk, den 11. april 2012, hentet ned den 19. februar 2016)

5) nej der trækkes kun med fem en halv bar (Dragepilot til pladsvagt, den 8 . august 2015)

6) Højeste temp. omkring $\mathbf{5}$ grader (www.dmi.dk, den 21. februar 2016)

7) Nettovægt: 200 g (Kornkammeret, pose med økologiske sesamfrø 2015)

Som det fremgår, kan strukturen realiseres grammatisk på forskellig vis. Den kan realiseres med et subjekt og et prædikativ forbundet af et kopula som i (2). Disse grammatiske kategorier har man traditionelt forbundet med prædikationen. Den centrale pointe i den økologisk funderede semantik er at den realiserede struktur adskiller sig fra en prædikation; der er ikke nogen entitet der prædiceres om eller tildeles en rolle, og der er ikke en definitionsmængde der tages over i en værdimængde. Det bliver endnu tydeligere når man sammenholder med de tetiske konstruktioner (3) og (4) der ligeledes realiserer strukturen, her ved substantivsyntagmer. Årsagen til at man har anset sådanne 
konstruktioner for emneløse i de etablerede beskrivelser, er at man har antaget at prædikationen er den basale meddelelseskonstituerende struktur (se Sasse 1987: 580, Lambrecht 1994: 177, Hansen \& Heltoft 2011: 1196-1199). I henhold til den økologisk funderede semantik er den basale meddelelseskonstituerende struktur imidlertid en angivelse af en værdi i en afgrænset mængde af gensidigt udelukkende værdier. Meddelelsers emne er ontologisk set en variation i miljøet, epistemologisk set en måde, dvs. en evne til at skelne mellem værdier af en variation i miljøet, og formelt set en afgrænset mængde af gensidigt udelukkende værdier af samme enhed.

Dansk omfatter, som andre sprog, en mængde leksikalske udtryk, ikke mindst substantiver, der kan anvendes til at identificere en måde, fx sigtbarbed, afstand, opdrift, hojde, hastighed, vindretning, vindstyrke, friktion, tryk, afdrift, kaliber, moment, kurs, trakestyrke, vagt, kurs, rente, lobetid og pris. Hvad den grammatiske realisering angår, er der imidlertid ikke en en til en-relation mellem identifikationen af måden og en grammatisk kategori ${ }^{6}$. Identifikationen af måden kan realiseres af subjektet som i (2). Men den kan også være kerneleddet i et substantivsyntagme hvor et adjektivsyntagme eller et præpositionssyntagme angiver værdien som i (3) og (4). Som det fremgår af (5), kan identifikationen af måden endvidere realiseres af en kombination af et verbum og en præposition (måden er her 'trækstyrke'). Og i eksempel (6) og (7) ser vi at realiseringen af måde-værdi-relationen ikke fordrer kopula; kolon som i (7) er en hyppig realisering af relationen i nogle genrer.

Men det der for alvor indikerer beskrivelsens potentiale, er at realiseringen af strukturen ikke fordrer at måden identificeres med et leksikalsk udtryk. Således begrænser den mest almindelige realisering af strukturen sig til en angivelse af en værdi (angivelse af værdi med fed):

8) så er der helt åbent herude men så er der jo (0.4) der er åbent fra den side men der jo ikke å (0.3) der er jo forholdsvis læ (0.7) fra den her side ikke

(Ledende sportsdirektør til ryttere, Hobro den 6. august 2014)

6 Ligesom der i øvrigt heller ikke er en-til-en-relation mellem det logiske subjekt og en grammatisk kategori eller mellem det referentielle emne og en grammatisk kategori. 
Meddelelserne indgår i udøvelsen af aktiviteten professionel landevejscykling. De stammer fra et taktikmøde mellem sportsdirektører og ryttere på et semiprofessionelt cykelhold 30 minutter før starten på 1 . etape af et internationalt etapeløb. For værdierne 'helt åbent', 'åbent' og 'forholdsvis læ' gælder det at de i aktiviteten indgår i en relativt velafgrænset mængde af gensidigt udelukkende værdier, nemlig den man i teknisk sprogbrug kalder topografisk effekt på vindhastighed. Det er ikke givet at deltagerne i denne interaktion kender denne term; men det er heller ikke nødvendigt: Det afgørende er at de er i stand til at skelne tilstrækkelig fint mellem de værdier topografiske effekter udgør, og er i stand til at dele dem så de kan koordinere forudsigelser og handlinger. En angivelse af en værdi kan med andre ord være tilstrækkelig til at man kan identificere den mængde værdien indgår i, og udelukke de alternative værdier. I den transaktion på 24 meddelelser de tre meddelelser stammer fra, er der faktisk ikke et eneste tilfælde hvor den mængde en angiven værdi indgår $i$, identificeres med et leksikalsk udtryk for mængden (Borchmann 2015b). Pragmatisk set kunne man altså sige at en angivelse af en værdi altid forudsætter at lytteren/læseren besidder evnen til at skelne mellem værdier i den mængde den angivne værdi indgår $i$, og semantisk set kunne man sige at en angivelse af en værdi kommer med en instruktion om at anvende denne evne i opsamlingen af informationen.

Dansk omfatter som en række andre sprog udtryk til at angive værdier der skal deles. De anvendte eksempler kan give det indtryk at det først og fremmest er numeralier, men en hvilken helst ordklasse kan bruges til at angive en værdi. Ligesom der ikke er en en til en-relation mellem identifikationen af delingsmåden og en grammatisk kategori, er der ikke heller ikke en en til en relation mellem angivelsen af den værdi der skal deles, og en grammatisk kategori. Der synes til gengæld at være den topologiske regelmæssighed at angivelsen af en værdi der skal deles, realiseres i fokusdomanet (Nølke 1994, Heltoft 2003) når meddelelsen realiseres med en simpel helsætning (Borchmann 2015b). Det er i det mindste en indikation på at den pragmatiske kategori 'angivelsen af den værdi der skal deles', er indkodet, og at der således er tale om en semantisk kategori i langue-lingvistisk forstand. 


\subsection{Indlejring}

For de værdier der meddeles i informativ udøversprogbrug, gælder det som nævnt i 3.1 at de varierer. Denne variation er betinget. Fx er RVRværdien 3000 fod betinget af tidspunktet og landingsbanen. I den økologisk funderede semantik beskrives denne betingelsesrelation med begrebet indlejring. Udtrykket indlejring er en oversættelse af Gibsons term nesting. Termen bruges om det forhold at den fysiske virkelighed er inddelt i enheder der er indlejret i større enheder på en lang række niveauer, men at der ikke er en særlig enhed miljøet kan analyseres $i$ en gang for alle. Det skelsættende ved den økologiske psykologi er antagelsen om at verden ikke perciperes i fysikkens, men i økologiens dimensioner, dvs. i dimensioner af den information der er relevant for vores liv (Gibson 1986: 306). Enhver værdi er indlejret i en enhed på et økologisk niveau.

Som det fremgik af 2.1, anses aktiviteten for at være den fundamentale økologiske enhed i denne beskrivelse. De to afgørende konsekvenser af dette valg er at enhver opsamling af en værdi er indlejret i en aktivitet, og at der - for så vidt som værdien er relevant - er en sammenhæng mellem en værdi der skal deles i en aktivitet, og andre værdier $i$ aktiviteten således at en værdi er betinget af andre værdier. I den præsenterede semantik betragtes en aktivitet med andre ord som et system.

Betingelsesrelationen mellem værdier beskrives med begrebet invarians (se 1.2.2 og 1.2.4). Invarians er en egenskab ved miljøet der gør værdier til en enhed på et økologisk niveau. I beskrivelsen skelnes der mellem invarians på fire forskellige niveauer. Det første og laveste niveau omfatter strukturer i stimuli der specificerer en handlemulighed. Det er strukturer i stimuli der specificerer fx sid-ned-barhed, kravle-over-barhed og sigtbarhed. I den semantik der præsenteres, omfatter det altså også grafiske og lydlige udtryksformer som three thousand, $44.3 \mathrm{~cm}$ og helt åbent samt andre symbolske former, fx et rødt lys i den øverste lygte på en lyskurv. Det der gør sådanne strukturer til en enhed på et økologisk niveau, er at de R-specificerer en handlemulighed. Når de er beskrevet som enheder, skal det fremhæves at det udelukkende er i kraft af at de indgår i en variation, at de specificerer en handlemulighed. 
Det andet niveau omfatter variationer. En variation er formelt set en afgrænset mængde af værdier, fx mængden af RVR-værdier, mængden af topografiske effekter på vindhastigheden eller mængden af lyskurvværdier [grøn, gul, rød]. Det kan sammenlignes med det man bl.a. i teknisk sprogbrug kalder en variabel. Det kan måske virke som en selvmodsigelse at bestemme en variation som en invarians; men det angiver den egenskab ved en variation at den er afgrænset, at de værdier den omfatter, er genkommende, og at værdierne er af samme enhed. For variationer i denne beskrivelse gælder det at deres afgrænsning er bestemt af aktiviteten. Der er fx afgørende forskelle på variationen i vandtemperaturer $i$ henholdsvis ølbrygning, triatlon og bagning.

Det tredje niveau omfatter relationer mellem variationer. En invariant relation er en sammenhæng mellem to variationer således at når værdien i den ene ændrer sig, så ændrer værdien sig i den anden og gør det efter et bestemt mønster. Det kan sammenlignes med det man i matematikken kalder en parameter. Eksempler på invariante relationer er relationen mellem tryk, volumen og tæthed, mellem sidevindsstyrke og afdrift, mellem topografiske forhold og vindhastighed, mellem vindretning, vindstyrke og sigtbarhed, mellem humlens kogetid og øllens bitterhed, mellem lokalitet og temperatur, mellem obligationsrente og obligationskurs, og mellem klokkeslet og adgangsmuligheden til en forretning. Invariante relationer er kausalrelationer, men som det fremgår af eksemplerne, gælder det at nogle kausalrelationer er uhyre komplekse og utilgængelige for os, og at virkningsforholdet kan bero på sociale konventioner.

Det fjerde og højeste niveau i beskrivelsen omfatter en kombination af relaterede variationer. Det svarer til det man i økologien kalder en niche, og som i denne semantik altså er en aktivitet.

\subsection{Indlejringsfunktionen}

En forudsætning for at dele værdier er at taleren/skriveren og lytteren/ læseren deler måde. Hvis de værdier der deles, er betingede, må de også dele betingelser. Disse betingelser er de værdier som værdien der skal 
deles, indgår i sammenhæng med i og med indlejringen i aktiviteten (se 3.3).

I udøvelsen af en række aktiviteter forekommer der situationer hvor taleren og lytteren både deler måde og betingelser. Det gælder fx et cockpit i et større jetfly under en startprocedure:

9) 15:25:20 Kaptajn: eighty (CVR-transskription, US Airways Flight 1549)

Her meddeler kaptajnen andenpiloten der styrer flyet, at hastighedsmåleren i kaptajnens side viser $80 \mathrm{knob}$ med den handlemulighed det indebærer, nemlig at de stadig kan nå at standse hvis der opstår motorbrand eller lignende kritiske funktionsfej $1^{7}$. Andenpilotens opsamling af denne værdi er betinget af at han deler tid og lokalitet med kaptajnen foruden at de deler måde. Og i situationen er det afgørende da flyet er under acceleration, og værdien og den handlemulighed den R-specificerer, efter ca. tolv sekunder ikke længere er til stede.

Hvor avanceret den ovenfor beskrevne opsamling af værdier end kan forekomme, adskiller den sig ikke væsentligt fra andre dyrs opsamling af værdier, $\mathrm{fx}$ en abes perception af en anden abes advarselsskrig med de handlemuligheder skriget R-specificerer. Den altafgørende forskel på menneskers sprog og andre dyrs tegnsystemer er at menneskers sprog gør det muligt at dele værdier selvom de ikke deler betingelser (Bühler 1934, Reed 1996, Deacon 1997, Harder 2010). Et menneske kan ved hjælp af sproget dele værdien 'helt åbent' selvom lytteren ikke har umiddelbar adgang til den handlemulighed den indebærer, enten fordi de ikke befinder sig på det sted hvor værdien kan opsamles, eller fordi værdien endnu ikke eksisterer. Denne egenskab ved sproget muliggør kollektiv prospektiv kontrol (Reed 1996: 156), og det er afgørende for samarbejdet om at realisere værdier og opnå tilsigtede udfald af aktiviteter. Men det er samtidig afgørende for det enkelte individs evner; for hvis det er muligt at udpege fraværende værdier for andre, må det også være muligt at udpege dem for en selv (Reed 1996: 171).

7 Desuden giver meddelelsen den information at begge hastighedsmålere virker hvis hastighedsmåleren $i$ andenpilotens side af cockpittet viser det samme værdi som den kaptajnen angiver med meddelelsen. 
Og det er grundlaget for at udvikle evnen til at tænke forstået som den autonome evne til at repræsentere aspekter af verden for sig selv.

For at en meddelelse kan anvendes til at dele en værdi selvom man ikke deler betingelser for at værdien kan opsamles, må sproget varetage endnu en funktion, nemlig at angive indlejringen af den værdi der skal deles. Denne funktion består ligeledes af to semantiske opgaver: en angivelse af den værdi der skal foreligge for at værdien der skal deles, kan opsamles, og en identifikation af den måde der skal anvendes i opsamlingen af den værdi der skal foreligge. Denne relation er altså også en relation mellem en værdi og en måde, og ligesom relationen mellem værdien der skal deles, og delingsmåden er det en udelukkelsesrelation. For at skelne værdien og måden der vedrører indlejringen, fra værdien der skal deles, og delingsmåden, bruges betegnelserne indlejringsverdien og indlejringsmåden. Relationen mellem disse to semantiske opgaver kaldes indlejringsfunktionen.

Angivelsen af indlejringsværdien kan være en angivelse af tid og sted, fx (indlejringsværdi med kursiv og værdi der skal deles, med fed):

10) På mandag morgen, når du skal af sted, er det frostgrader (www. dmi.dk 09.01.2014)

11) så er der helt åbent herude [taleren peger på et rutekort]

Men det kan også være en række andre værdier, fx:

12) Med en 100 grains Oryx er der en afdrift på $44.3 \mathrm{~cm}$ ved $5 \mathrm{~m} / \mathrm{s}$ på 300 meter

13) Forudsat korrekt tempo er vinderchancen 74 pct.

I (12) er afdriftsværdien 44,3 cm betinget af kuglevægten 100 grains, kugletypen Oryx, sidevindsstyrken $5 \mathrm{~m} / \mathrm{s}$ og afstanden 300 meter. I (13), der meddeler chancen for at vinde et bestemt antal stik i et kortspil, er chancen på 74 pct. betinget af en bestemt timing (tempo) af spilhandlinger.

Hvad den sproglige realisering angår, omfatter dansk en række morfemer, ord og ordforbindelser til at angive indlejringsværdier. Det er bl.a. præpositionsforbindelser, se (10) og (12), adverbier, se (11), adjek- 
tiver, se (13), og substantiver. Men også tempusbøjningen kan anvendes. Der er et vist overlap mellem udtryk der angiver indlejringsværdier, og udtryk der angiver værdier der skal deles. Der er imidlertid den afgørende forskel på den sproglige realisering af indlejringsværdien og værdien der skal deles, at den første kan være udeladt mens det aldrig kan forekomme for den anden. Hvad den grammatiske realisering af indlejringsværdiens angivelse angår, er der ikke en en til en-relation mellem angivelsen og grammatiske kategorier. Der synes imidlertid at gælde den topologiske regelmæssighed at angivelsen af indlejringsværdier ikke optræder i fokusdomanet (Nølke 1994, Heltoft 2003), men at de ofte realiseres som frie adverbialer til højre for indholdsfeltet eller i fundamentfeltet (Hansen \& Heltoft 2011). De kan imidlertid også realiseres som subjekt på subjektspladsen eller i fundamentfeltet. Men det er også sådan at angivelsen af indlejringsværdier ofte realiseres i koteksten eller i paratekster.

For identifikationen af indlejringsmåden gælder det at de leksikalske udtryk der kan anvendes til at identificere delingsmåder, også kan anvendes til at identificere indlejringsmåder, se (13) hvor substantivet "tempo" identificerer indlejringsmåden. Men generelt er det sådan at identifikationen af indlejringsmåden $i$ endnu mindre omfang end identifikationen af delingsmåden er realiseret ved et leksikalsk udtryk. Denne forskel viser sig i eksempel (12); her er det udelukkende delingsmåden afdrift der er realiseret ved et leksikalsk udtryk mens indlejringsmåderne kuglevægt, kugletype, sidevindsstyrke og afstand kun er sprogligt repræsenteret ved en værdi der indgår i de mængder måderne formelt set udgør. Da identifikationen af indlejringsmåden kun i ringe omfang synes at være realiseret ved et leksikalsk udtryk i informativ udøversprogbrug, er der ikke noget godt grundlag for at bestemme dens grammatiske realisering. Det skal så tilføjes at leksikalske realiseringer af identifikationer af måder først og fremmest synes at forekomme i formativ udøversprogbrug. Og her har jeg altså begrænset mig til informativ udøversprogbrug.

\subsection{Den basale semantiske struktur deling-indlejring}

Ovenfor har jeg redegjort for to funktioner: delingsfunktionen og indlejringsfunktionen. Den basale semantiske struktur deling-indlejring er 
en relation mellem disse to funktioner. Denne relation er en dobbelt relation. Logisk set er det en ensidig betingelsesrelation: En taler/skriver der angiver en indlejringsværdi og en værdi der skal deles, forpligter sig på at værdien der skal deles, kan opsamles hvis indlejringsværdien kan opsamles, men ikke på at indlejringsværdien kan opsamles hvis værdien der skal deles, kan opsamles. Med (11) som eksempel kan relationen altså fremstilles sådan: 'Hvis kuglevægten er 100 grains, kugletypen er Oryx, sidevindsstyrken er $5 \mathrm{~m} / \mathrm{s}$, og afstanden er 300 meter, så er afdriften $44.3 \mathrm{~cm}$.' For så vidt svarer relationen til det man i logikken kalder en implikation. I den økologisk funderede semantik er relationen imidlertid ikke en relation mellem udsagn eller prædikationer, men mellem værdier. Derforuden adskiller relationen sig fra implikationen ved at den også indebærer en prioritering af information med hensyn til relevans; konsekventen (i eksemplet '44,3 cm') har status som det der efterspørges af lytteren/læseren, og tilfredsstiller det behov der motiverer den sproglige interaktion. Det er med andre ord den relevante information. Uden information med denne status, ingen meddelelse. Mens antecendenten (i eksemplet 'Oryx ', '100 grains', '5 m/s' og '300 m') logisk set er en betingelse for konsekventen $44,3 \mathrm{~cm}$, er afhængighedsforholdet kommunikationslogisk set omvendt: Indlejringsværdierne er udelukkende værdier i kraft af deres relation til værdien der skal deles; de forudsætter en angivelse af en værdi der skal deles. Denne forskel i status ytrer sig dels ved at angivelsen af indlejringsværdier kan udelades, se fx (9), dels ved at indlejringsværdierne kan bestemmes af lytteren/læseren forud for interaktionen, se fx harpunfiskeren (sektion 2) der vælger betingelsen 'i aften' for opsamlingen af vindstyrkeværdien og vindretningsværdien.

Denne dobbelte relation mellem delingsfunktionen og indlejringsfunktionen er den anden basale semantiske struktur der postuleres. Da denne relation ligesom de to andre relationer er en formålsbestemt relatering af semantiske opgaver, kaldes den også en funktion, og da den altså relaterer funktioner, anses den for en overordnet funktion. Denne overordnede funktion kaldes meddelelsesfunktionen. Påstanden er at denne overordnede funktion regulerer udformningen af meddelelser $\mathrm{i}$ informativ udøversprogbrug og resulterer $\mathrm{i}$ et antal sproglige 
mønstre. Disse mønstre hævdes at være egenskaber ved et sprog som redskab til at dele information.

Da varetagelsen af de fire opgaver antages at være en betingelse for at dele en værdi der varierer, kan beskrivelsen tjene som en heuristik der dels indebærer at man leder efter udtryk der varetager opgaver, uden for den sætning der indeholder angivelsen af værdien, dels tillader indkatalyseringen af leksikalske udtryk der specificerer varetagelsen af en opgave der ikke er varetaget af et leksikalsk udtryk. Således kan man lave følgende analyser af nogle af de eksempler der er anvendt ovenfor:

it's three thousand RVR

Delingsmåde: RVR

Indlejringsmåder: tidspunkt og landingsbane

Meddelelsesfunktion: RVR som funktion af tidspunkt og landingsbane

Indlejringsværdier: kommunikationstidspunktet [angivet med præsensbøjningen], Chicago Midway 31C [angivet i en ytring i en forudgående interaktion] Værdi der skal deles: three thousand

Med en 100 grains Oryx er der en afdrift på $44.3 \mathrm{~cm}$ ved $5 \mathrm{~m} / \mathrm{s}$ på 300 meter

Delingsmåde: afdrift

Indlejringsmåde: kuglevægt, kugletype, sidevindsstyrke og afstand

Meddelelsesfunktion: afdrift som funktion af kuglevægt, kugletype, sidevindsstyrke og afstand

Indlejringsværdier: 100 grains, Oryx, 5 m/s, 300 meter

Værdi der skal deles: $44,3 \mathrm{~cm}$

så er der helt åbent herude

Delingsmåde: topografisk effekt på vindhastighed

Indlejringsmåde: lokalitet

Meddelelsesfunktion: topografisk effekt på vindhastighed som funktion af lokalitet

Indlejringsværdi: herude [taleren peger på et rutekort]

Værdi der skal deles: helt åbent 
Forudsat korrekt tempo er vinderchancen 74 pct.

Delingsmåde: vinderchance

Indlejringsmåde: tempo

Meddelelsesfunktion: vinderchance som funktion af tempo

Indlejringsværdi: korrekt

Værdi der skal deles: 74 pct.

Disse analyser og karakteristikker hævdes at have en større forklaringsværdi for meddelelser der indgår $\mathrm{i}$ udøvelsen af aktiviteter, end de analyser og karakteristikker der kendetegner EBSM.

\section{SAMMENFATNING}

Epistemologisk set er den afgørende pointe at den viden udøvere af aktiviteter besidder, ikke er tavs. Den viser sig i sprogbrug der indgår $i$ udøvelsen af aktiviteter, nemlig ved øvede udøveres selektion, prioritering og relatering af information. Det kan man imidlertid ikke se hvis man anvender de traditionelle semantiske beskrivelser. En beskrivelse af relationen mellem sprog og den viden udøvere af aktiviteter besidder, fordrer en ny semantik med en ny pragmatisk ramme. Jeg har argumenteret for at Gibsons teori om handlemuligheder kan anvendes som grundlag for en ny pragmatisk ramme, og jeg har tillempet Gibsons begreb om en specifikationsrelation mellem information og handlemuligheder så den omfatter redskabsmedierede relationer.

Pragmatisk set er det en afgørende pointe at det empiriske grundlag for beskrivelsen af de strukturer der regulerer udformningen af meddelelser, må være sprogbrug der indgår $\mathrm{i}$ udøvelsen af aktiviteter, og hvor man kan skelne mellem sproglige mønstre og de ikkesproglige materielle konsekvenser de kan forårsage. Antagelsen er at det er i disse aktiviteter semantiske restriktioner dannes, stabiliseres, henter deres legitimitet og kan sanktioneres.

I artiklen har jeg kritiseret de etablerede sprogvidenskabelige beskrivelser af naturlige sprogs meddelelsesstruktur. Min beskrivelse kan på sin side kritiseres for ikke at leve op til de krav man fra en languelingvistisk synsvinkel stiller til en semantik. For jeg har ikke påvist at 
samtlige de fire opgaver jeg har hævdet at et sprog skal varetage, er kodet $i$ et sprog. Der ligger altså stadig et arbejde forud for en økologisk psykologisk funderet funktionel semantik som en langue-lingvistisk beskrivelse. Med dette udkast har jeg i det mindste gjort det muligt undersøge om de fire opgaver er kodet. Indtil da kan beskrivelsen tjene som en retvisende og informativ pragmatisk analyse af meddelelser der indgår i udøvelsen af aktiviteter.

\author{
Simon Borchmann \\ Institut for Kommunikation og Humanistisk Videnskab \\ Roskilde Universitet \\ sub@ruc.dk
}




\section{LITTERATUR}

Adolph, Karen E. 2008. Learning to move. Current Directions in Psychological Science 17. 213-218.

Adolph, Karen E. \& Kari S. Kretch. 2015. Gibson's theory of perceptual learning. International encyclopedia of the social and behavioral sciences, 2. udg., Vol.10. New York, NY: Elsevier. 127-134.

Bartlett, Frederic C. 1932. Remembering: A study in experimental and social psychology. Cambridge: Cambridge University Press.

Borchmann, Simon. 2015a. Tetiske sætninger i udøversprogbrug. Inger Schoonderbeek \& Tina. T. Hougaard (red.), 15. mode om udforskningen af dansk sprog. 47-68. Århus: Institut for Kommunikation og Kultur, Aarhus Universitet.

Borchmann, Simon. 2015b. "Fordi man ved aldrig": emne, fokus og kohærens i informativ udøversprogbrug. Skandinaviske Sprogstudier 6(4). 17-107.

Bühler, Karl. 1934. Sprachttheorie. Jena: Fischer.

Deacon, Terrence. 1997. The Symbolic Species. The co-evolution of language and the brain. New York: WW. Norton \& Company.

Federal Aviation Administration. 2006. Performance specification PC based runway visual range (RV R) System. Lighting systems office RV R product team (AJW-46). Department of Transportation.

Gibson, Eleanor J. \& Anne D. Pick. 2000. An ecological approach to perceptual learning and development. New York: Oxford University Press.

Gibson, Eleanor J. 1969. Principles of perceptual learning and development. New York: Appleton-Century Crofts.

Gibson, Eleanor J. \& Nancy Rader. 1979. Attention: The perceiver as performer. Gordon A. Hale \& Michael Lewis (red.), Attention and cognitive development, 1-21. New York \& London: Plenum Press.

Gibson, James J. 1986. The ecological approach to visual perception. New York: Psychology Press.

Gibson, James J. 1966. The senses considered as perceptual systems. Boston: Houghton Mifflin Company.

Gibson, James J. \& Eleanor J. Gibson. 1955. Perceptual learning: Differentiation or enrichment? Psychological Review 62. 32-41.

Hansen, Erik \& Lars Heltoft. 2011. Grammatik over det danske sprog. København: Det Danske Sprog- og Litteraturselskab.

Harder, Peter 2010. Meaning in mind and society. Berlin: De Gruyter Mouton. 
Heltoft, Lars 2003. Iconic and categorial focus systems in Scandinavian. Jorunn Hetland \& Valéria Molnár (red.), Structures of focus and grammatical relations, 41-86. Tübingen: Max Niemeyer Verlag.

Hodges, Bert H. 2009. Ecological pragmatics: Values, dialogical arrays, complexity, and caring. Pragmatics \& Cognition 17(3). 628-652.

Hodges, Bert H. 2007. Good prospects: ecological and social perspectives on conforming, creating, and caring in conversation. Language Sciences 29. 584-604.

Hodges, Bert H. \& Reuben M. Baron. 1992. Values as constraints on affordances: Perceiving and acting properly. Journal for the Theory of Social Behaviour 22. 263-294.

Krifka, Manfred \& Renate Musan. 2012. Information structure: Overview and linguistic issues. Manfred Krifka, Renate Musan \& Wolfgang Klein (red.), Expression of cognitive categories: Expression of information structure, 1-44. München: Walter de Gruyter.

National Transportation Safety Board. 2007. Runway overrun and collision, Soutbwest Airlines Flight 1248, Boeing 737-7H4, N471WN, Chicago Midway International Airport, Chicago, Illinois, December 8, 2005. Aircraft accident report. Washington, DC.

Kuno, Susumu. 1972. Functional sentence perspective: A case study from Japanese and English. Linguistic Inquiry 3. 269-320.

Kuroda, Sige-Yuki. 1972. The categorical and the thetic judgment. Foundations of Language 9. 153-185.

Kuroda, Sige-Yuki. 2005. Focusing on the matter of topic: A study of Wa and Ga in Japanese. Journal of East Asian Linguistics 14(1). 1-58.

Lambrecht, Knud. 1994. Information structure and sentence form. Cambridge: Cambridge University Press.

Nølke, Henning. 1994. Informationsstruktur. Med fokus på fokus. Hermes 13, 251-279. Århus: Handelshøjskolen i Århus, Det Erhvervssproglige Fakultet.

Odling-Smee, John F., Kevin N. Laland \& Marcus W. Feldman. 2003. Niche construction: The neglected process in evolution. New Jersey: Princeton University Press.

Reed, Edward S. 1996. Encountering the world. New York, NY: Oxford University Press.

Sasse, Hans Jürgen 1987. The thetic/categorical distinction revisited. Linguistics 25. 511-580.

Searle, John 1995. The construction of social reality. London: Penquin.

Togeby, Ole. 2003. Fungerer denne satning? København: Gads Forlag.

Vygotsky, Lev. 1978. Mind in society. The development of higher psychological processes. Cambridge: Harvard University Press. 
Zukow-Goldring, Patricia \& Michael A. Arbib. 2007. Affordances, effectivities, and assisted imitation: Caregivers and the directing of attention. Neurocomputing 70. 2181-2193. 